\title{
Economic Consequences of COVID-19 in the Middle East and North Africa Region Countries
}

\author{
Seyed Mohammad Hashemi-Shahri (D), Eshagh Barfar * (D), Alireza Ansari-Moghaddam (iD), \\ Fatemeh Setoodehzadeh (D), Mohammad Khammarnia (iD), Hassan Okati-Aliabad (iD
}

Health Promotion Research Center, Zahedan University of Medical Sciences, Zahedan, Iran

\begin{tabular}{|c|c|}
\hline Article Info & ABSTRACT \\
\hline doi $10.30699 /$ jambs.28.131.304 & \multirow{4}{*}{$\begin{array}{l}\text { Since the first reported case of coronavirus disease } 2019 \text { (COVID-19) in Wuhan, } \\
\text { China, on December } 30,2019 \text {, the number of confirmed cases of the disease has } \\
\text { increased continuously and exponentially. The event has emerged as a clear threat } \\
\text { to global health, such that the World Health Organization (WHO) officially declared } \\
\text { it a pandemic on March } 11,2020 \text {. The disease has infected approximately } 1,891,000 \\
\text { people and killed around } 50,200 \text { in the Eastern Mediterranean region until } 29 \text { th } \\
\text { August } 2020 . \text { As COVID-19 spreads globally, its economic consequences are also } \\
\text { mounting across all countries. In this perspective study, we briefly discuss the } \\
\text { economic consequences of COVID-19 in the Middle East and North Africa } \\
\text { (MENA) region countries. } \\
\text { Keywords: Coronavirus Disease } 2019 \text {, COVID-19, Economic Consequences, } \\
\text { MENA }\end{array}$} \\
\hline $\begin{array}{c}\text { Received: 2020/05/05; } \\
\text { Accepted: 2020/09/09; } \\
\text { Published Online: } 21 \text { Oct } 2020\end{array}$ & \\
\hline $\begin{array}{l}\text { Use your device to scan and read the } \\
\text { article online }\end{array}$ & \\
\hline 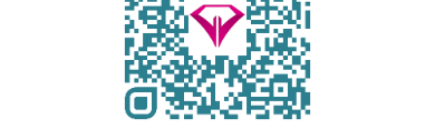 & \\
\hline $\begin{array}{l}\text { Corresponding Information: } \\
\text { Eshagh Barfar, } \\
\text { Health Promotion Research Center, } \\
\text { Zahedan University of Medical Sciences, } \\
\text { Zahedan, Iran } \\
\text { E-Mail: } \\
\text { eshaghbarfar@gmail.com }\end{array}$ & \\
\hline
\end{tabular}

(C) (i) (s) Copyright $(\mathcal{C} 2020$, This is an original open-access article distributed under the terms of the Creative Commons Attribution-noncommercial 4.0 International License which permits copy and redistribution of the material just in noncommercial usages with proper citation.

\section{Introduction}

From the first reported case of coronavirus disease 2019 (COVID-19) in Wuhan, China, on December 30, 2019 , the number of confirmed cases has increased continuously and exponentially up to now (1). At the time of writing of this article (August 29, 2020), the virus has spread around the planet affecting 216 countries and areas or territories with a total of around $24,600,000$ confirmed cases and more than 830,000 deaths worldwide (2). COVID-19 has emerged as a clear threat to global health, such that the World Health Organization (WHO) officially declared it a pandemic on March 11, 2020 (3). Accordingly, the disease has infected approximately $1,891,000$ people and killed around 50,200 in the Eastern Mediterranean region. With a total of 369,911 confirmed cases and 21,249 deaths, Iran has the highest morbidity and mortality rate in the region until 29th August 2020. (2).

As COVID-19 spreads globally, its economic consequences are also mounting across all countries. Before the outbreak, the global economy seemed to be improving; however, the spread of the disease has brought significant disruptions and damages to the global economy, especially in developing countries. In this perspective research, we briefly discuss the economic consequences of COVID-19 in the Middle East and North Africa (MENA) region countries.

\section{The Global Economic Consequences of COVID-19}

The current epidemic is economically different from the previous post-World War II epidemics. Those epidemics mainly affected countries that did not play an important role in the global economy at that time with a much smaller extent. However, at this time, the Group of Seven countries (G7) and China are also affected (4). Additionally, COVID-19 pandemic statistics and expansion change every hour to the extent that currently, the countries with the highest incidence and death rates are almost the world's largest economies (excluding Iran) (2).

The effects of such pandemic on the growth and development of global and regional economics are not yet fully understood, but some initial estimates suggest significant losses. Approximations by McKibbin and Fernando showed that the event will result in a $6.7 \%$ loss in global Gross Domestic Product (GDP) and an 8.4\% loss for both United States (US) and the Eurozone 
GDP in 2020. According to the evidence, even a lowlevel COVID-19 epidemic could reduce the world's GDP by around $\$ 2.4$ trillion, and a high-level epidemic would reduce the world's GDP by $\$ 9$ trillion (5). On the other hand, Boon predicted a decrease in global GDP growth by 0.5 to $1.5 \%$ in 2020 (4). The International Monetary Fund (IMF) also predicted a $3 \%$ decrease in global GDP growth in 2020 (6). In general, due to weakened GDP, poverty can create a vicious cycle of destructive effects on the economy and health. For example, the rapid escalation of cases in the MENA region countries, especially Iran, led officials to close schools and universities in the first step. They closed many businesses, artistic venues, and cinematic events, and they implemented a policy of social distancing. Neighboring countries also closed their land and sea borders with Iran. Other MENA countries have reported an outbreak as well. The ability to control the virus in these countries depends on the ability of their health systems. Most MENA countries rank relatively well among the world's 191 health systems based on WHO ranking (7).

Nevertheless, some MENA countries appear to be struggling with the event. War in countries like Syria and Yemen will hinder the proper function of their health systems. The US sanctions against Iran could also considerably damage Iran's capacity to provide necessary equipment in order to prevent and control coronavirus (8). Forecasts by the IMF indicate that the economy of the Middle East and North Africa regions will shrink 4\% and $1.7 \%$, respectively, in 2020 (6). The IMF and the World Bank had forecasted a 0\% GDP growth in Iran in 2020 before the COVID-19 outbreak $(6,9)$; given the event, the IMF says that Iran's GDP will shrink by $6 \%$ this year (6). This shrink in GDP can lead to an unemployment crisis and affect the wellbeing of many households. Declining business activities leads to government tax revenues. Therefore, due to the reduction of the government's capacity to collect taxes, it will face a budget deficit.

The Economic Consequences of COVID-19 in MENA Region Countries

As a result of the COVID-19 epidemic in MENA region countries, both demands and supplies of goods and services within these areas are being weakened and deteriorated (5). The service sector in these countries is directly affected by the disease. Extensive damage to industries and services such as transportation, tourism, ports, restaurants, clothing, passenger terminals, education, and recreation, has been imposed due to widespread restrictions on passenger and labor movements and diminished demand. In addition, Saudi Arabia has even suspended the entry of pilgrims to holy sites (10). COVID-19 has also had a significant negative impact on oil demand. Therefore, it is expected that the devastating effects of the disease will be strongly felt in the MENA region countries due to the oil dependency of the region countries and exporting its products, as well as experiencing a noticeable reduction in the price of oil products nowadays (4).

Since the virus was discovered and the disease has been on the rise in China and other countries in early 2020, oil prices have fallen sharply. The Organization of Petroleum Exporting Countries (OPEC) oil price has fallen around $83 \%$, from $\$ 70.89$ on January 7 to $\$ 12.22$ on April 23 per barrel. Due to declining oil, tax, and toll revenues, as well as unexpected expenditures of controlling the disease, most governments are likely to face significant budget deficits.

The global impact of COVID-19 on supplying services and production is like a complicated web. The increased rates of morbidity and mortality of the disease lead to disruption of trade, work closures, and production restrictions. Sick workers also take more time off, which can reduce production. In fact, the COVID-19 pandemic has proven the centrality of manpower in economic activity once again. Severe disruptions in the regional and global supply chain will make it more difficult and/or costly to obtain necessary industrial imports from other countries. The decline in stock indices and the disruption of direct supply that hinders production will lead to the closure of many factories and, eventually, to its destructive impact on other countries (11).

\section{Post-COVID-19 World}

Undoubtedly, the consequences of the COVID-19 pandemic will affect human life for many years, especially in the MENA region countries. The event could impede health, economic, political, and social progress in these countries. Also, perhaps like World War II, it will be the basis for many changes in the aftermath. In terms of health, it is predicted that people will make significant changes in their lifestyles, both personally and occupationally. People's health literacy will increase, and many health habits will be developed. The allocation of government resources to the health sector will also increase. Although the destructive effects of the COVID-19 pandemic can be seen in all countries, its economic effects on developing countries are much more severe. Similar to earthquakes or floods, the disease can destroy many of the economic structures in a short period taking years to be rebuilt. In the post-coronavirus disease 2019 era, we may see a significant growth in Internet businesses, and one strategy could be the online performance of every activity, including business, education, and the provision of required resources and food for families. We will probably see crowded courts (both financial, criminal, and family) due to returned checks and noncommitment to contracts. Other COVID-19-related consequences may highlight the supportive role of governments in the economy, a power shift and influence from West to East, a less prosperous world, globalization disruption, as well as changing educational and employment systems. 


\section{Conclusion}

Dealing with the COVID-19 epidemic requires consistent, centralized, pragmatic, decisive, transparent, fast, intelligent, and scientific management with the highest national and international interactions. The most important policy recommendations for governments to moderate the effects of the event on the economies of the MENA region countries, including Iran, could be as follows: continuation of policies such as social distancing to the stage of disease control, emergency reduction of interest rates on loans by the central bank, providing special banking facilities to businesses that have been affected by the disease pandemic, the expansion of financial aid to people affected by the policy of social distancing or faced with a sharp decline in income, reducing profit tax, the central bank liquidity support of commercial banks, postponing energy bills, paying bonuses to health workers, providing prevention equipment (such as masks, gloves, and disinfectants) for all households, increasing international cooperation to reduce disease damage and attracting financial and technical aids from developed countries, opening up a political dialogue to reduce tensions in war-torn countries and a political dialogue to persuade the international community not to comply with the US unilateral sanctions that have endangered the lives of millions of Iranians and, consequently, the health of the human population.

\section{Acknowledgments}

The authors thank all those who helped them writing this article.

\section{Ethical considerations}

Ethical issues (Including plagiarism, informed consent, misconduct, data fabrication and/or falsification, double publication and/or submission, redundancy, etc.) have been completely observed by the authors.

\section{Conflict of Interest}

Authors declared no conflict of interest.

\section{Funding and support}

This research resulted from an independent research without receiving any financial support.

\section{How to Cite This Article:}

\section{References}

1. Dong E, Du H, Gardner L .An interactive webbased dashboard to track COVID-19 in real time. Lancet Infect Dis; published online Feb 192020. [DOI:10.1016/S1473-3099(20)30120-1]

2. WHO. WHO Coronavirus Disease (COVID-19) Dashboard. https://covid19.who.int/ . (Accessed Aug 29, 2020).

3. WHO. WHO Director-General's opening remarks at the media briefing on COVID-19 -11 March 2020. March 11, 2020 https:/www.who.int/dg/speeches/detail/whodirector-general-s-opening-remarks-at-the-mediabriefing-on-covid-19---11-march-2020

(Accessed Aug 29, 2020).

4. Baldwin R and Di Mauro BW. Economics in the Time of COVID-19. London, UK: CEPR Press; 2020 .

5. McKibbin W , Fernando R. The global macroeconomic impacts of COVID-19: Seven scenarios. CAMA Working Paper. 2020. [DOI:10.2139/ssrn.3547729]

6. IMF. Datasets, World Economic Outlook, Gross Domestic Product (GDP), Real GDP growth. https://www.imf.org/external/datamapper/NGDP RPCH@WEO/IRN?year=2020. (Accessed April $\overline{2} 6,2020)$

7. Tandon A, Murray CJL, Lauer JA, Evans DB. Measuring overall health system performance for 191 countries. Geneva: World Health Organization; 2000.

8. Takian A, Raoofi A, Kazempour-Ardebili S. COVID-19 battle during the toughest sanctions against Iran. Lancet. 2020; (395)10229: 1035-6. [DOI:10.1016/S0140-6736(20)30668-1]

9. The World Bank. Data, Countries and Economies, Iran. https://data.worldbank.org/country/iranislamic-rep. (Accessed April 26, 2020).

10. Algaissi AA, Alharbi NK, Hassanain M, Hashem AM. Preparedness and response to COVID-19 in Saudi Arabia: Building on MERS Experience. J Infect Public Health. 2020; 13: 834-38. [DOI:10.1016/i.jiph.2020.04.016]

11. Ayittey FK, Ayittey MK, Chiwero NB, Kamasah JS, Dzuvor C. Economic impacts of Wuhan 2019$\mathrm{nCoV}$ on China and the world. J Med Virol. 2020; 92: 473-75. [DOI:10.1002/jmv.25706] 